\title{
CRP/Lymphocyte Ratio in Patients with COVID-19 with Headache
}

\section{Baş Ağrısı Olan COVID-19 Hastalarında CRP/Lenfosit Oranı}

\author{
Şaziye Melike Işık, @Meltem Karacan Gölen, @Dilek Yılmaz Okuyan
}

Konya Numune State Hospital Department of Neurology, Konya, Turkey

\begin{abstract}
Aim: One of the most common neurologic symptoms observed in COVID-19 is headache. The pathogenesis of this headache is still not clearly defined. In our study, we aimed to reveal the relationship between headache observed in patients with COVID-19 and the C-reactive protein CRP/ lymphocyte ratio, an indicator of inflammation.
\end{abstract}

Material and Method: The demographic, clinical, and laboratory characteristics of patients followed up with a diagnosis of COVID-19 were recorded. The clinical and laboratory findings of patients with and without headache were compared.

Results: A total of 106 patients were included in the study. The mean age of all patients was $60.81 \pm 15.03$ years and $50.9 \%$ were male. The mean age of the patient group with headache $(57.77 \pm 15.42$ years) was significantly lower than the mean age of the group without headache $(64.22 \pm 13.95$ years) $(p=0.027)$. The smoking rate was also higher in this group ( $p=0.003$ ). Smell and taste disorders were also found to be significantly higher in patients with headache compared with patients without headache $(p=0.003)$. When the groups were compared in terms of the CRP/lymphocyte ratio, no significant difference was found $(p<0.05)$.

Conclusion: Our study is important in that it is the first to examine the CRP/lymphocyte ratio in patients with headache. It can be a guide for future studies with larger patient groups.

Keywords: COVID-19, SARS-CoV-2 infection, headache, C-reactive protein, inflammation, CRP/lymphocyte ratio
Öz

Amaç: COVID-19'da izlenen en sık nörolojik semptomlardan birisi baş ağrısıdır. Bu baş ağrısının patogenezi halen net olarak tanımlanamamıştır. Çalışmamızda COVID-19 enfeksiyonunda izlenen baş ağrısının bir enflamasyon göstergesi olan CRP/ Lenfosit oranı ile ilişkisini ortaya koymayı amaçladık.

Gereç ve Yöntem: COVID-19 tanısı ile izlenen hastaların demografik, klinik ve laboratuvar özellikleri kaydedildi. Baş ağrısı olan ve olmayan hastaların klinik ve laboratuvar bulguları karşılaştıııldı.

Bulgular: Çalışmaya toplam 106 hasta dahil edildi. Tüm hastaların yaş ortalaması 60.81 ( \pm 15.03) ve \%50.9'u erkekti.

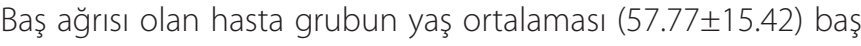
ağrısı olmayan grubun yaş ortalamasına $(64.22 \pm 13.95)$ göre anlamlı düşük bulundu ( $p=0.027$ ). Bu grupta sigara kullanma oranı da yüksekti ( $p=0.003$ ). Yine baş ağrısı olanlarda koku ve tat alma bozukluğu semptomu baş ağrısı olmayan hastalara göre anlamlı oranda yüksek bulundu (P=0.003). Gruplar CRP/Lenfosit oranı açısından karşılaşı̧ııılığında anlamlı fark saptanmadı $(p<0.05)$.

Sonuç: Çalışmamız baş ağrısı olan hastalarda CRP/Lenfosit oranını irdeleyen ilk çalışma olması bakımından önemlidir. Daha büyük hasta grupları ile yapılacak ileriye dönük çalışmalar için yol gösterici olabilir.

Anahtar Kelimeler: COVID-19, SARS-CoV-2 Enfeksiyonu, Baş ağrısı, C-Reactive Protein, Inflamasyon, CRP/Lenfosit Oranı

Corresponding (illetişim): Şaziye Melike Işık, Konya Numune State Hospital Department of Neurology, Hospital Street, No:22 Selcuklu/Konya, 


\section{INTRODUCTION}

Coronavirus disease 2019 (COVID-19) was defined as a global pandemic by the World Health Organization (WHO) in early March 2020. It has been demonstrated that the novel coronavirus, which is a single-stranded RNA virus, is primarily effective on the lungs, but can also affect multisystems, especially the renal, hematologic, and neurologic systems.

Headache is one of the common neurologic manifestations observed in patients with COVID-19, and it has been shown to occur at rates of $6.7 \%$ to $40 \% .[1,2]$ The pathogenesis of headache observed in COVID-19 has not been fully explained. The first possibility may be that severe acute respiratory syndrome coronavirus 2 (SARS-CoV-2) directly invades the trigeminal nerve endings in the nasal cavity.[3] This situation has been associated with angiotensin-converting enzyme 2 (ACE2) expression in neurons.[4] The second possibility is trigeminovascular activation based on vascular pathogenesis with the participation of endothelial cells known to have ACE2 expression. Another possible mechanism is related to proinflammatory mediators and cytokines released due to the virus.[3]

The $\mathrm{S} 1$ subset of the SARS-CoV-2 surface spike protein binds to the ACE2 receptor, triggering the production of angiotensin-1. ACE then converts angiotensin-1 to angiotensin-2, which binds to the angiotensin receptor and raises endothelin-1 (ET1) levels. This results in a diffuse inflammatory response with the release of pro-inflammatory cytokines and interleukins (IL). $[5,6]$ Large-scale unregulated production of ILs, particularly IL-6, activate multiple pathways. They increase the production of acute-phase reactants such as C-reactive protein (CRP) and the mobilization of neutrophils.[7] Thus, together with stress-induced neutrophilia, relative lymphopenia seen in severe manifestations of SARS-CoV2 infection develops.[810] This indicates that the parameter expressed as the CRP/ lymphocyte ratio may be an indicator of the severity of inflammation. Typically, the CRP/lymphocyte ratio is used as a prognostic marker for various types of cancer, including gastric carcinoma and colon cancer.[11, 12] The rationale behind this is that the CRP/lymphocyte ratio also serves as a good representative of the complex host-tumor immunologic interactions that result in the systemic inflammatory process believed to contribute to the pathogenesis and progression of these carcinomas.[13] It can be concluded that the CRP/ lymphocyte ratio may be a good marker in this disease process and have prognostic value because COVID-19 triggers different immunologic mechanisms and accelerates a systemic inflammatory response.[14]

Studies showing that the CRP/lymphocyte ratio is associated with COVID-19-associated pneumonia and can be used as a biomarker in predicting prognosis suggest that this parameter is a strong indicator of inflammation. In this study, we aimed to reveal the relationship between the CRP/lymphocyte ratio and headache, considering that the headache observed in COVID-19 was related to the severity of inflammation.

\section{MATERIAL AND METHOD}

\section{Study Design and Patients}

In this retrospective observational study, patients who were admitted to our hospital between April and November 2020 and were diagnosed as having COVID-19 according to the WHO guide[15] were included. The study was conducted in accordance with the ethical standards of the responsible institution on human subjects and the Declaration of Helsinki. Approval was obtained from the Local Ethics Committee (Protocol No: 2021/025) and the Ministry of Health for this retrospective study.

Clinical, demographic, and laboratory data were extracted from electronic medical records using a standardized data collection form. The records of a total of 122 patients aged over 18 years were analyzed for the study. A total of 106 patients were included in the analyses after excluding those with a history of head trauma, malignancy or cerebrovascular disease, those who were diagnosed as having COVID-19 in their follow-up, and those who were pregnant. Headache was diagnosed according to the International Classification of Headache Disorders.[16]

The diagnosis of COVID-19 was made using respiratory tract swab samples (throat swabs) with real-time qualitative polymerase chain reaction (RT-qPCR). Among the data regarding the main comorbidities, a history of diabetes mellitus (DM), hypertension (HT), chronic obstructive pulmonary disease (COPD), and coronary artery disease (CAD) were recorded. Routine blood work, complete blood count, serum biochemical tests CRP, D-dimer, myocardial enzymes (troponin), and serum ferritin values were recorded.

\section{Statistical Analysis}

Whether the continuous variables were normally distributed was evaluated using the Shapiro-Wilk test. Student's t-test (for data with normal distribution) and the Mann-Whitney $U$ test (for data without normal distribution) were used to compare the two groups. The Chi-square test was used to investigate the relationship between categorical variables. A general linear model was applied to adjust for the possible effect of age and smoking. Statistical analysis was performed using the SPSS for Windows version 24.0 software package. A significance level of 0.05 was used in the analyses.

\section{RESULTS}

A total of 106 consecutive patients with a confirmed diagnosis of COVID-19 were included in our study. Just over half the patients (50.9\%) were male. The mean age was $60.81 \pm 15.03$ years and the most common comorbidities were HT (19.8\%) and DM (18.9\%). Of the patients, $15.1 \%$ were smokers (Table 1). The mean white blood cell (WBC) count was $7.63 \pm 3.5$ (normal range, 4.49-12.68) 109/L, the neutrophil count was $5.56 \pm 3.07$ (normal range 2.1-8.89) 109/L, the monocyte count was $0.54 \pm 0.27$ (normal range 0.25-0.84) $109 / \mathrm{L}$, the 
platelet count was 242.43 \pm 97.21 (normal range 173-390) $109 / \mathrm{L}$, the ferritin level was $280.05 \pm 262.81$ (normal range, 23.9-336.2) $\mathrm{ng} / \mathrm{mL}$, the $D$-dimer level was $0.69 \pm 1.18$ (normal range $0-0.5) \mu \mathrm{g} / \mathrm{mL}$, and the troponin level was $11.05 \pm 16.12$ (normal range 0-19.8) ng/L (Table 2).

Table 1. Descriptive Characteristics of the Patients

\begin{tabular}{lc} 
& $\mathbf{n}(\%)$ \\
\hline Sex (male) & $54(50.9)$ \\
Contact history & $23(22.6)$ \\
Hyposmia-hypogeusia & $41(38.7)$ \\
Headache & $56(52.8)$ \\
Comorbidity & $52(49.1)$ \\
Diabetes mellitus & $20(18.9)$ \\
Hypertension & $21(19.8)$ \\
Coronary artery disease & $4(3.8)$ \\
Chronic obstructive pulmonary disease & $6(5.7)$ \\
\hline
\end{tabular}

Table 2. Laboratory Parameters of the Patients

\begin{tabular}{lc}
\hline Variables (n=106) & Median (Min-Max) \\
\hline WBC (109/L) & $6.66(3.35-23.8)$ \\
Neutrophil (109/L) & $4,54(1.65-15.9)$ \\
Lymphocyte (109/L) & $1.15(0.46-5.64)$ \\
Monocyte (109/L) & $0.5(0.18-1.74)$ \\
Platelet (109/L) & $223(71-624)$ \\
CRP (mg/L) & $63.6(1.5-407)$ \\
Ferritin (ng/mL) & $169.9(7.6-1368)$ \\
D-dimer ( $\mathrm{Mg} / \mathrm{mL})$ & $0.37(0.02-9.68)$ \\
Troponin (ng/L) & $7(1.3-99.7)$ \\
CRP/lymphocyte ratio & $50(0.78-536)$ \\
\hline WBC:White Blood Cell, CRP: C-reactive protein. &
\end{tabular}

The mean lymphocyte count was $1.28 \pm 0.67$ (normal range 1.26-3.35) $109 / \mathrm{L}$, and the mean CRP level was $75.56 \pm 66.74$ (normal range $0-8$ ) $\mathrm{mg} / \mathrm{L}$. The mean CRP/lymphocyte ratio of the patients was $77.23 \pm 86.17$.

The patients were divided into two groups as those with and without headache ( $n=56$ and $n=50$, respectively) and compared. The groups were similar in terms of sex distribution $(p<0.05)$. The mean age of the patient group with headache $(57.77 \pm 15.42$ years) was significantly lower than the mean age of the group without headache $(64.22 \pm 13.95$ years) $(p=0.027)$. The smoking rate was also higher in this group $(p=0.003)$. Smell and taste disorders were also found to be significantly higher in patients with headache compared with patients without headache $(p=0.003)$. When the groups were compared in terms of the CRP/lymphocyte ratio, no significant difference was found $(p<0.05)$. There was no significant difference when the CRP/lymphocyte ratio was compared again after the effect of age and smoking, which were different between the groups, was eliminated using a linear model $(p=0.343)$ (Table 3)
Table 3. Comparison of laboratory parameters of patients with and without headache

Variables

(Mean \pm SD)

WBC $\left(10^{9} / \mathrm{L}\right)$

Neutrophil $\left(10^{9} / \mathrm{L}\right)$

Lymphocyte $(10 \% / \mathrm{L})$

Monocyte $\left(10^{9} / \mathrm{L}\right)$

Platelet $(10 \% / \mathrm{L})$

CRP (mg/L)

Ferritin $(\mathrm{ng} / \mathrm{mL})$

D-dimer $(\mu \mathrm{g} / \mathrm{mL})$

Troponin (ng/L)

Headache (+) Headache (-)

$(n=56)$

$7.85 \pm 3.99$

$(\mathrm{n}=\mathbf{5 0})$

$7.38 \pm 2.86$

$5.95 \pm 3.59$

$5.14 \pm 2.32$

$1.32 \pm 0.8$

$1.24 \pm 0.5$

$0.55 \pm 0.3$

$0.54 \pm 0.23$

$243.84 \pm 98.3$

$240.86 \pm 96.94$

$67 \pm 53.38$

$85.14 \pm 78.54$

$274.46 \pm 239.72$

$286.31 \pm 288.83$

$0.5 \pm 0.58$

$0.91 \pm 1.59$

$8.78+13.33$

$13.59 \pm 18.58$

CRP/lymphocyte ratio

$69.27 \pm 73.59$

$86.15 \pm 98.37$

*WBC:

Mann white blood cell, CRP: C-reactive protein. + Significant at 0.05 level; Student t-test for age,

Mann-Whitney U test for other numerical variables, Padjusted: General linear model; results adjusted by age and smoking.

\section{DISCUSSION}

COVID-19 is a rapidly spreading, pandemic infection. It was first identified with an outbreak that began in December 2019 in Wuhan, China. In their study with 138 patients, Wang et al. reported the mean age of the patients as 56.0 years.[17] Of the patients in that study, $54.3 \%$ were male and $45.7 \%$ were female. In the study of Huang et al. in which 1733 patients were included, $52 \%$ of the patients were male and the median age was 57.0 years.[18] In our study, $50.9 \%$ of the patients were male. The mean age was $60.81 \pm 15.03$ years.

The clinical course in COVID-19 may vary according to underlying diseases. Huang et al. reported that $32 \%$ of 41 patients had an underlying disease; that they found DM in $20 \%, \mathrm{HT}$ in $15 \%$, and cardiovascular disease in $15 \%$ of patients. [19] In another study, Lai et al. found that the most common underlying diseases in adult patients were $\mathrm{HT}$, cardiovascular disease, and DM.[20] In our study, HT and DM were found to be the most common underlying diseases.

Headache was detected in $52.8 \%$ of the patients in our study, and the mean age of patients with headache was found to be lower than those without headache. In a large, multicenter, prospective European study by Lechien et al. in which 1420 patients with COVID-19 were evaluated, it was reported that headache was more common in young people compared with the elderly.[21] Although this finding was explained by the low mean age of the patients (mean age 39 years), similar findings in our study indicated that more comprehensive and detailed studies were needed on this subject.

Another finding of our study was that the rate of smoking was higher in the group with headache compared with those without headache. The functional similarity between the nicotinic acetylcholine receptor (nAChR) and ACE2 suggests that smoking may promote cellular entry of SARS-CoV2 via nAChR signaling.[22] The higher prevalence of COVID19related neurologic symptoms such as headache in smokers can be explained by the same cells expressing nAChR and ACE2 in the central nervous system (CNS).[22] 
Giacomelli et al. showed that postviral smell and/or taste disorders were detected in $33.9 \%$ of individuals infected with SARS-CoV-2.[23] This rate was shown to increase up to $68 \%$ in different studies.[24] The source of this dysfunction in COVID-19 may be the transneural penetration of SARS-CoV through the olfactory bulb.[25] Another possible mechanism is the presence of the transmembrane ACE2 receptor, which is detected in the cranial nerves related to smell and taste and is a necessary component for SARS-CoV2 binding.[4] Smell and/or taste disorders were detected in $38.7 \%$ of the patients included in our study. The frequency of hyposmia/hypogeusia in patients with headache was significantly higher than in patients without headache. Our findings support the view that CNS involvement in COVID-19 may be mediated by transneural penetration or the ACE2 receptor.

CRP is known to play an important role in innate immunity as an early defense mechanism against infections. It was shown in previous studies that the level of CRP was high in patients with COVID-19 and that this level was even correlated with the severity of pneumonia.[26, 27] In our study, the mean CRP value of all patients was $75.56 \pm 66.74 \mathrm{mg} / \mathrm{L}$, which was above the reference range $(0-8 \mathrm{mg} / \mathrm{L})$, as expected. There was no significant difference in mean CRP levels between patients with and without headache $(p<0.05)$.

One of the common hematologic findings in patients with COVID-19 is lymphopenia.[19, 28] $\mathrm{Ni}$ et al. showed that severe lymphopenia was correlated with the severity of COVID-19 and that the number of T lymphocytes (especially CD8+ and CD4+ subset) increased significantly with effective treatment, and this increase was associated with a decrease in proinflammatory cytokines in the serum after treatment.[29] In our study, the mean lymphocyte count of the patients was $1.28 \pm 0.67109 / \mathrm{L}$ and was within the normal range. Due to the nature of our study design, this could be explained by the fact that the blood samples studied were those of patients under treatment; blood samples at the time of admission were not studied. There was no difference in terms of mean lymphocyte count between patients with and without headache.

In our study, the CRP/ymphocyte ratio was used as an inflammation marker based on the possible effects of the severity of inflammation on the secondary headache mechanism. There was no significant difference in terms of CRP/lymphocyte ratios between patients with and without headache $(p<0.05)$. It should be considered that current approaches used in the treatment of COVID-19, especially steroid therapy [30] and immunotherapies [31], may affect the CRP/lymphocyte ratio.

Our study had some limitations. The most important limitation of our study is that the treatments used by the patients were not examined. The relatively small number of patients is another limitation.

\section{CONCLUSION}

Our findings are important because this is the first study to examine the relationship between the CRP/lymphocyte ratio and headache in patients with COVID-19. The higher incidence of COVID-19 headache in smokers and the frequency of olfactory-taste disorder association in those with headache may be a guide for studies to elucidate the pathogenesis of pain. Prospective studies with larger patient groups are required to reveal the pathogenesis of headache in SARSCoV2 infections.

\section{ETHICAL DECLARATIONS}

Ethics Committee Approval: Approval was obtained from the Local Ethics Committee (Protocol No: 2021/025) and the Ministry of Health for this study.

Informed Consent: All patients signed the free and informed consent form.

Referee Evaluation Process: Externally peer-reviewed.

Conflict of Interest Statement: The authors have no conflicts of interest to declare.

Financial Disclosure: The authors declared that this study has received no financial support.

Author Contributions: All of the authors declare that they have all participated in the design, execution, and analysis of the paper, and that they have approved the final version.

\section{REFERENCES}

1. Ding Q, Lu P, Fan Y, Xia Y, Liu M. The clinical characteristics of pneumonia patients coinfected with 2019 novel coronavirus and influenza virus in Wuhan, China. J Med Virol 2020;92(9):1549-55.

2. Tian S, Hu N, Lou J, et al. Characteristics of COVID-19 infection in Beijing. J Infect 2020;80(4):401-6.

3. Bolay H, Gül A, Baykan B. COVID-19 is a Real Headache! Headache 2020;60(7):1415-21.

4. Doobay MF, Talman LS, Obr TD, Tian X, Davisson RL, Lazartigues E. Differential expression of neuronal ACE2 in transgenic mice with overexpression of the brain renin-angiotensin system. Am J Physiol Regul Integr Comp Physiol 2007;292(1):373-81.

5. Song W, Gui M, Wang X, Xiang Y. Cryo-EM structure of the SARS coronavirus spike glycoprotein in complex with its host cell receptor ACE2. PLoS Pathog 2018;14(8):e1007236.

6. Perlman S, Netland J. Coronaviruses post-SARS:update on replication and pathogenesis. Nat Rev Microbiol 2009;7(6):439-50.

7. Beniac DR, Andonov A, Grudeski E, Booth TF. Architecture of the SARS coronavirus prefusion spike. Nat Struct Mol Biol 2006;13(8):751-2.

8. Ruan Q, Yang K, Wang W, Jiang L, Song J. Clinical predictors of mortality due to COVID-19 based on an analysis of data of 150 patients from Wuhan, China. Intensive Care Med 2020;46(5):846-8.

9. Millet JK, Whittaker GR. Host cell entry of Middle East respiratory syndrome coronavirus after two-step, furin-mediated activation of the spike protein. Proc Natl Acad Sci U S A 2014;111(42):15214-9.

10. Liu Y, Du X, Chen J, Jin Y, et al. Neutrophil-to-lymphocyte ratio as an independent risk factor for mortality in hospitalized patients with COVID-19. J Infect 2020;81(1):6-12.

11. Koike Y, Miki C, Okugawa Y, et al. Preoperative C-reactive protein as a prognostic and therapeutic marker for colorectal cancer. J Surg Oncol 2008;98(7):540-4. 
12. Okugawa $Y$, Toiyama $Y$, Yamamoto $A$, et al. Lymphocyte-C-reactive Protein Ratio as Promising New Marker for Predicting Surgical and Oncological Outcomes in Colorectal Cancer. Ann Surg 2020;272(2):342-51.

13. Bacha S, Sghaier A, Habibech S, et al. Combined C-reactive protein and Neutrophil to Lymphocyte ratio use predict survival innon-small-cell lung cancer. Tunis Med 2017;95(12):229-35.

14. Ullah W, Basyal B, Tariq S, et al. Lymphocyte-to-C-Reactive Protein Ratio:A Novel Predictor of Adverse Outcomes in COVID-19. J Clin Med Res 2020;12(7):415-22.

15. Organization WH. Clinical management of COVID-19:interim guidance, 27 May 2020. In:World Health Organization;2020.

16. The International Classification of Headache Disorders, 3rd edition (beta version). Cephalalgia 2013;33(9):629-808.

17. Wang D, Hu B, Hu C, et al. Clinical Characteristics of 138 Hospitalized Patients With 2019 Novel Coronavirus-Infected Pneumonia in Wuhan, China. Jama 2020;323(11):1061-9.

18. Huang C, Huang L, Wang Y, et al. 6-month consequences of COVID-19 in patients discharged from hospital:a cohort study. Lancet 2021;397(10270):220-32.

19. Huang C, Wang Y, Li X, et al. Clinical features of patients infected with 2019 novel coronavirus in Wuhan, China. Lancet 2020;395(10223):497-506.

20. Lai CC, Shih TP, Ko WC, Tang HJ, Hsueh PR. Severe acute respiratory syndrome coronavirus 2 (SARS-CoV-2) and coronavirus disease-2019 (COVID-19):The epidemic and the challenges. Int J Antimicrob Agents 2020;55(3):105924.

21. Lechien JR, Chiesa-Estomba CM, Place S, et al. Clinical and epidemiological characteristics of 1420 European patients with mild-to-moderate coronavirus disease 2019. J Intern Med 2020;288(3):335-44.

22. Kabbani N, Olds JL. Does COVID19 Infect the Brain? If So, Smokers Might Be at a Higher Risk. Mol Pharmacol 2020;97(5):351-3.

23. Giacomelli A, Pezzati L, Conti F, et al. Self-reported Olfactory and Taste Disorders in Patients With Severe Acute Respiratory Coronavirus 2 Infection:A Cross-sectional Study. Clin Infect Dis 2020;71(15):889-90.

24. Meng X, Deng Y, Dai Z, Meng Z. COVID-19 and anosmia:A review based on up-to-date knowledge. Am J Otolaryngol 2020;41(5):102581.

25. Netland J, Meyerholz DK, Moore S, Cassell M, Perlman S. Severe acute respiratory syndrome coronavirus infection causes neuronal death in the absence of encephalitis in mice transgenic for human ACE2. J Virol 2008;82(15):7264-75.

26. Wang L. C-reactive protein levels in the early stage of COVID-19. Med Mal Infect 2020;50(4):332-4.

27. Rodriguez-Morales AJ, Cardona-Ospina JA, Gutiérrez-Ocampo E, et al. Clinical, laboratory and imaging features of COVID-19:A systematic review and meta-analysis. Travel Med Infect Dis 2020;34:101623.

28. Chen N, Zhou M, Dong X, et al. Epidemiological and clinical characteristics of 99 cases of 2019 novel coronavirus pneumonia in Wuhan, China:a descriptive study. Lancet 2020;395(10223):507-13.

29. Ni M, Tian FB, Xiang DD, Yu B. Characteristics of inflammatory factors and lymphocyte subsets in patients with severe COVID-19. J Med Virol 2020;92(11):2600-06.

30. Selvaraj V, Dapaah-Afriyie K, Finn A, Flanigan TP. Short-Term Dexamethasone in Sars-CoV-2 Patients. R I Med J (2013) 2020;103(6):3943.

31. Gluck WL, Callahan SP, Brevetta RA, et al. Efficacy of therapeutic plasma exchange in the treatment of penn class 3 and 4 cytokine release syndrome complicating COVID-19. Respir Med 2020;175:106188. 